$ノ-ト$

\section{ネオクプロイン-銅 $(\mathrm{I})$ 錯陽イオンを用 \\ いたレニゥムの溶媒抽出吸光光度定量 \\ 法と間接原子吸光定量法}

\author{
大久保悌二，松田 正治* \\ (1976 年 10 月 8 日受理)
}

1 緒言

レニウムの原子吸光定量はアセチレンー亜酸化窒素炎 などを用いても感度が低く, 桜井1) は抽出原子吸光法に よって感度が著しく向上することを報告している。山 本2）金属キレート陽イオンによる陰イオンの吸光光度 定量法と間接原子吸光定量法を検討し, 多くの陰イオン を高感度で定量している. 小辻ら゙)が $2,2^{\prime}$-ビピリジル鉄(II) キレートによるレニウムの 溶媒抽出吸光光度定 量法を報告しているようにレニウム水溶液中では過レニ ウム酸イオンが安定であり, 銅のように原子吸光分析で 感度の高い普通金属のキレート陽イオンを用いる間接原 子吸光法が適用できるならば特殊な光源やバーナーを備 えなくとも微量のレニウムが定量できる. Senise ら゙) は 銅(II) のアジ化物-2, 2'-ビピリジル 錯体を用い, 抽出 吸光光度法ビピリジル錯体を用い, 抽出吸光光度法と間 接原子吸光法によりレニウムを分析できることを報告し ている. 本研究によれば, 過レニウム酸イオンはヒドロ キシルアミンで還元されず, Senise らの方法より単純な ネオクプロインー銅(I) キレート陽イオンを用いれば, 空試験值も少なく, 微量のレニウムの定量に適用できる ことが明らかになったので報告する。

$$
2 \text { 実験 }
$$

\section{$2 \cdot 1$ 装}

分光光度測定には島津 UV-200 分光光度計を用い, 原子吸光度測定には島津 AA-610 原子吸光分光光度計, アセチレンー空気炎を用いた。

\section{2 試薬}

レニウム標準溶液: 市販過レニウム酸カリウム $(99.9$

* 工業技術院東京工業試験所：東京都湴谷区本町 11-5
\%) $1.554 \mathrm{~g}$ を 11 の水に溶かし，レニウム $1 \mathrm{mg} / \mathrm{ml}$ 溶 液とした。

ネオクプロインは和光純楽(株)製のものを，宅の他の 試薬は市販特級品をそのまま使用した。

\section{2 .3 定量操作}

あらかじめ $\mathrm{pH}$ を 2 4 に調節した試料溶液 $(15 \mathrm{ml}$ 以下）に $3 \mathrm{ml} の 0.11 \mathrm{w} / \mathrm{v} \%$ 硫酸銅 5 水塩水溶液, $5 \mathrm{ml}$ の $3.4 \mathrm{w} / \mathrm{v} \%$ リン酸二水素カリウム水溶液, $2 \mathrm{ml}$ の $5 \mathrm{w} / \mathrm{v} \%$ 硫酸七ドロキシルアミン水溶液を加えた後, 水で全体を $25 \mathrm{ml}$ とし， $0.042 \mathrm{w} / \mathrm{v} \%$ ネオクプロイン の酶酸エチル溶液 $10 \mathrm{ml}$ を加え, 3 分間激しく振り混ぜ る.しばらく静置して液相が分離したら水相を捨て, 有 機相を無水硫酸ナトリウム結晶を加えて脱水する. 吸光 光度法による場合は，この有機相の $456 \mathrm{~nm}$ における吸 光度を測定し，原子吸光法による場合は銅の中空陰極う ンプを用いて $324.8 \mathrm{~nm}$ の原子吸光度を測定して，レニ ウムの定量を行う.

\section{3 実験結果と考察}

\section{1 抽出溶媒の選択}

有機溶媒を变元，レニウム $100 \mu \mathrm{g}$ を含む試料液と空 試験液について定量操作を行い，吸光度を測定してみた ところ, 空試験值が低く, 過レニウム酸の存在で吸光度 が高い酶酸エチルが抽出溶媒として適当であることが分 かった，nーヘキサン，シクロヘキサン，ベンゼンなど誘 電率の低いものには錯体が抽出されにくく, ジクロロエ タン，メチルイソブチルケトン，ニトロベンゼンなど誘 電率の高いものでは空試験值が高くなるため抽出溶媒と して不適当であった.

\section{2 抽出条件}

銅一ネオクプロイン錯陽イオンは pH 3〜10 の範囲で 生成することは Smith ら5)によって報告されている. 又, Collinson 56) は過塭素酸イオンの抽出吸光光度 定量と間接原子吸光定量にこの錯陽イオンを利用してい る. 過レニウム酸は $\mathrm{pH} 1$ 以上でヒドロキシルアミン やアスコルビン酸などによって還元されず，定量操作に おける挙動は過塩素酸イオンとほぼ同一であったので, Collinson らの過酸素酸イオンの定量方法と同じ条件老 適用した. Table 1 に示すように抽出操作の繰り返しは 誤差を大きくするので，抽出は完全ではないが，10 ml の溶媒で 1 回だけ抽出することにした.

\section{3 吸光光度定量の箅囲}

定量操作に従って得られる抽出有機相の可視部吸収に 
Table 1 Analytical test by spectrophotometric method (rhenium added $50 \mu \mathrm{g}$ )

\begin{tabular}{ccccc}
\hline $\begin{array}{c}\text { Extract } \\
\text { time }\end{array}$ & $\begin{array}{c}\text { Volume of } \\
\text { organic solvent } \\
(\mathrm{ml})\end{array}$ & $\begin{array}{c}\text { Percent } \\
\text { extraction }\end{array}$ & $\begin{array}{c}\text { Mean of 10 } \\
\text { repetition } \\
(\mu \mathrm{g})\end{array}$ & $\begin{array}{c}\text { Standard } \\
\text { deviation } \\
(\mu \mathrm{g})\end{array}$ \\
\hline 1 & 10 & 97.0 & 49.8 & 1.37 \\
2 & 5 & 99.7 & 49.7 & 1.82 \\
2 & 10 & 99.9 & 50.2 & 2.04 \\
\hline
\end{tabular}

は $456 \mathrm{~nm}$ 付近に極大があり，この波長におけるモル吸 光係数は $7.3 \times 10^{3}$ で，(5〜250) $\mu \mathrm{g}$ のレニウムの定量 ができる・検量線はこの範囲で直線であった。

\section{4 間接原子吸光定量の範囲}

前記の定量操作に従い，レニウムの間接原子吸光定量 を行うとき，酢酸エチル溶媒は黒煙が出やすく，炎が安 定しにくい，黑煙を防ぐために空気量を多くすると試料 を吸い込えでいないときに炎が吹き消されやすいなど， 炎の条件が難しい，これを容易にするため，抽出溶媒を 揮散させ，残留する鍇化合物を一定量の水，メタノール などに溶解させて原子吸光度を測定することもできる が，操作を速やかに行うため，メタノールで 5 倍に希釈 して測定した。このときの感度は $0.13 \mu \mathrm{g} / \mathrm{ml} / 1 \%$ (吸 収）でアアセチレンー西酸化窒素炎を用いた抽出原子吸 光法1)と此較して 10 倍の感度に相当する. この操作の 空試験で $5 \mu \mathrm{g}$ のレニウムに相当する 銅キレート陽イオ ンが抽出される．銅の原子吸光の感度は高いが，空試験 值以下では䛊差が大きくなり，レニウムの定量には燠さ ない. 又, メタノールによる 5 倍希釈は，炎を安定化さ せ，测定值のばらつきを少なくするので，定量の下限を 不利にするものではない. 従って, この方法で $5 \mu \mathrm{g}$ 以 上 $150 \mu \mathrm{g}$ までのレニウムの定量ができる.

\section{5 共存イオンの影響}

レニウム $100 \mu \mathrm{g}$ を含む試料にいくつかのイオンを加 え, 吸光光度法によって得られた定量值を Table 2 に 示す. 陽イオンとリン酸, 硫酸などの多価の陰イオンの 影響は小さいが, 多量のハロゲンイオン, 硝酸イオン, チオシアン酸イオンは誤差の原因となる外, 過塩素酸イ オンは少量でも大きな誤差を与える. 又, 多量のモリブ デンはネオクプロインー銅錯陽イオンと難溶性の沈殿を 生成し，レニウムの抽出を妨げ，俱の誤差を与光る. 四 光光度法では抽出された錯陽イオンの吸収を測定してい るのに比べ，閒接原子吸光法はこの錯陽イオン中の銅の 原子吸収を測定しているので，間接原子吸光法でも吸光 光度法と全く同じ影響がある。
Table 2 Effect of diverse ions

\begin{tabular}{lcc}
\hline Ions & $\begin{array}{c}\text { Present } \\
(\mathrm{mg})\end{array}$ & $\begin{array}{c}\text { Rhenium found } \dagger \\
(\mu \mathrm{g})\end{array}$ \\
\hline $\mathrm{Cl}^{-}$ & 0.5 & 102 \\
& 2.0 & 108 \\
$\mathrm{Br}^{-}$ & 6.0 & 129 \\
& 1.0 & 109 \\
$\mathrm{I}^{-}$ & 6.0 & 161 \\
$\mathrm{NO}_{3}{ }^{-}$ & 1.0 & 148 \\
$\mathrm{SCN}^{-}$ & 1.0 & 132 \\
$\mathrm{ClO}_{4}{ }^{-}$ & 1.0 & 158 \\
$\mathrm{PO}_{4}{ }^{3-}$ & 0.1 & 250 \\
$\mathrm{SO}_{4}^{2-}$ & 10.0 & 105 \\
$\mathrm{MoO}_{4}{ }^{2-}$ & 10.0 & 103 \\
& 1.67 & 97 \\
$\mathrm{Fe}^{3+}$ & 8.34 & 34 \\
$\mathrm{Al}^{3+}$ & 1.0 & 100 \\
$\mathrm{Mg}^{2+}$ & 1.0 & 98 \\
$\mathrm{Ca}^{2+}$ & 2.0 & 101 \\
& 2.0 & 102 \\
\hline
\end{tabular}

$\dagger 100 \mu \mathrm{g}$ of rhenium is added in each case.

リン酸トリブチル逆相クロマトグラフィー7)により， これらの妨害イオンとレニウムを分離すれば，得られる 過レニウム酸溶液はわずかに硫酸を含むだけで，この定 量法と組み合わせることによって微量のレニウムが容易 に定量できる. $\left(\begin{array}{l}1975 \text { 年 } 10 \text { 月, 日本分析化学 } \\ \text { 会第 } 24 \text { 年会において講演 }\end{array}\right)$

\section{交献}

1) 桜井兵一郎: 本誌, 24, 52 (1975).

2) 山本勇麓: 同上, 21, 418 (1972).

3) 小辻奎也，桜井俊之，山本勇麓：日化，86,741 (1965).

4) P. Senise, L. G. Silva : Anal. Chim. Acta, 80, 319 (1975).

5) G. F. Smith, W. H. McGurdy : Anal. Chem., 24, 371 (1952).

6) W. J. Collinson, D. F. Boltz : ibid., 40, 1896 (1968).

7）大久保悌二：本誌，22，1231 (1973).

拧

Spectrophotometric and indirect atomic absorption spectrophotometric determination of rhenium by using solvent extraction of the ionpair of bis(neocuproin) copper(I) perrhenate. Teiji Ônubo and Shoji Matsuda (National Chemical Laboratory for Industry, 1-1-5, Honmachi, Shibuyaku, Tokyo)

Perrhenate anion forms ion-pair compound with neocuproin copper(I) chelate cation and is extracted into ethyl acetate. The extracted species shows orange color and an absorption maximum exists at $456 \mathrm{~nm}$. The measurement of the species in the organic phase by spectrophotometric method as well as the measurement of extracted copper by atomic absorption spectrophotometric method allow determination of micro- 
amount of rhenium. The recommended procedures are as follows: To the sample solution $(\mathrm{pH} 3$ to 5), add $3 \mathrm{ml}$ of $0.11 \%$ cupric sulfate solution, $5 \mathrm{ml}$ of $3.4 \%$ potassium dihydrogen phosphate solution and $2 \mathrm{ml}$ of $5 \%$ hydroxylamine sulfate solution. Adjust the volume to about $25 \mathrm{ml}$ with water, shake the solution for $3 \mathrm{~min}$ with $10 \mathrm{ml}$ of ethyl acetate containing $0.042 \%$ of neocuproin. Separate the organic phase and dehydrate it with sodium sulfate anhydride. Determine rhenium concentration by either spectrophotometry or indirect atomic absorption spectrophotometry. The molar extinction coefficient of the species in ethyl acetate is $7.3 \times 10^{3}$. Both methods are applicable to determination of more than $5 \mu \mathrm{g}$ of rhenium. More than $1 \mathrm{mg}$ of molybdenum interfere with the determination.

(Received Oct. 8, 1976)

\section{Keywords}

Extraction spectrophotometry

Indirect atomic absorption spectrophotometry

Neocuproin-copper chelate

Rhenium

\section{新アゾ系指示薬による負コロイドの 直接滴定}

桐栄恭二，宮田崝夫，小野俊朗*

(1976 年 10 月 1 日受理)

$$
1 \text { 緒 } \overrightarrow{\overline{\bar{a}}}
$$

コロイド滴定法1)2) は電解質コロイドを定量する方法 である. 正コロイドに対しては負コロイドであるポリビ ニル硫酸カリウム (PVSK) を滴定剤として, 又負コロ イドに対しては過剩量の Cat-Floc ${ }^{3)}$ を加えて 沈殿を作 り，その過剩分を PVSK で滴定する方法が用いられて いる. この場合指示薬はカチオン染料のトルイジンブル 一 (TB) が用いられている. すなわち, 天然に数多く 存在する負コロイド試料の定量には適当な指示薬の無い まま，TBを用いた間接滴定がなされている。

最近, 直接滴定の指示薬として Calcon4) が月用いられ たが，著者らは更にこれらの指示薬について検討し，そ

* 岡山大学理学部化学教室 : 岡山県岡山市津島中 $3-$ 1-1
の結果， 6 種のアゾ系色素を合成した。その中から次の 構造をもつ NBS \{3-(2-ヒドロキシー3-カルボキシアニ リド-1-アゾナフタレン)-4-ヒドロキシベンゼンスルホ ン酸 が適用 $\mathrm{pH}$ 域 $(6.5 \sim 11)$ も広く色調変化も良好 であったので，これを用いて数種の負コロイド試料を滴 定した.それらの中で PVSK，アルギン酸ナトリウム，

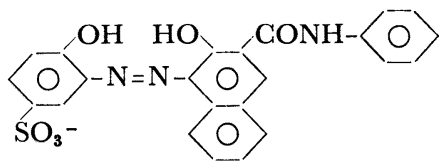

ポリアクリル酸ナトリウムが定量可能であったので報告 ケる。

$$
2 \text { 実験 }
$$

\section{1 試 薬}

NBS : $0.001 \mathrm{M}$ 溶液を(1〜3) 滴用いた.なお, 合成 は Acid Alizarin Violet N5) と同様に行い, エタノ一 ルから 2 回再結晶し暗かっ色の結晶を得た.

N/400 PVSK (和光純薬), N/400 Cat-Floc (米国力 ルゴン社)， TB は既報3）に従って調製した。

$\mathrm{pH}$ は水酸化ナトリウム水溶液を用いて調整した.

負コロイド試料：ポリビニル硫酸カリウム，フルギン 酸ナトリウム(東京化成製 1 級), ポリアクリル酸ナト リウム (三晶製), カラゲニン (同), 硫酸セルロースナ トリウム (同), コンドロイチン硫酸ナトリウム（和光 純薬製 1 級), リグニンスルホン酸ナトリウム（東京化 成製 1 級) をそれぞれ $(50 \sim 60)^{\circ} \mathrm{C}$ で減圧乾燥して恒量 としたものを再蒸留水に溶かして用いた

\section{2 操 作}

直接滴定は試料を NBS を指示薬として N/400 CatFloc 溶液で滴定した. 又, 間接滴定は従来どおり試料 に過剩の Cat-Floc 溶液を加方, 過剩分を N/400 PVSK 溶液で TB を指示薬として敵定した. それぞれの溶液 のかき混ぜにはテフロン製回転子をもったマグネチック スターラーを用い, $\mathrm{pH}$ は滴定終了後にも測定した.

\section{3 実験絬果}

\subsection{Cat-Floc の規定度の決定法}

Cat-Floc の規定度の決定は間接滴定法では TB を川 いた従来の方法6)によった。直接滴定では NBS を用 い，規定度既知の PVSK6) を Cat-Floc で补定し，そ の㵜定值より規定度を決定した。

\subsection{NBS の適用度}

NBS は pH 6.5〜11 の間で指示萎こして伐用でき， 終点での変色は中性付近では紫から青, 塩基性領域では 